\title{
Genetic diversity and condition factor: a significant relationship in Flemish but not in German populations of the European bullhead (Cottus gobio L.)
}

\author{
G Knaepkens ${ }^{1,2}$, D Knapen ${ }^{2,3}$, L Bervoets ${ }^{3}$, B Hänfling ${ }^{4}$, E Verheyen ${ }^{2}$ and M Eens ${ }^{1}$ \\ ${ }^{1}$ University of Antwerp - UIA, Universiteitsplein 1, Antwerp, Belgium; ${ }^{2}$ Royal Belgian Institute of Natural Sciences, Vautierstraat \\ 29, Brussels, Belgium; ${ }^{3}$ University of Antwerp — RUCA, Groenenborgerlaan 171, Antwerp, Belgium; ${ }^{4}$ University of Hull, Hull \\ HU6 $7 R X, U K$
}

\begin{abstract}
Although evidence of associations between genetic diversity and fitness in wild species has been published, the lack of a comprehensive review across species and the existence of contradictory results have led to scepticism remaining about its existence and importance in natural populations. In this study, the relationship between genetic diversity at six microsatellite loci and condition factor (a fitness related trait) was investigated at the population level in both Flemish and German populations of the European bullhead (Cottus gobio). A significant positive correlation was observed
\end{abstract}

between genetic variability and the condition factor in Flemish but not in German bullhead populations. Environmental conditions such as conductivity of the water seemed more important in determining the condition factor of these latter populations. Regardless of the underlying mechanism(s) responsible for the different relationships, the results of this study suggest that both genetic and environmental variables can influence condition factor of bullhead populations.

Heredity (2002) 89, 280-287. doi:10.1038/sj.hdy.6800133

Keywords: condition factor; Cottus gobio; environment; fitness; genetic diversity; microsatellite

\section{Introduction}

Genetic diversity is generally regarded to be important for the survival of natural populations, because it allows them to maintain high levels of fitness and adapt to changing environmental conditions (Frankel and Soulé, 1981). Consequently, intraspecific genetic diversity has been recognised as one of the three levels of biological diversity requiring conservation (McNeely et al, 1990). However, due to the widespread destruction of natural habitats, populations nowadays are becoming smaller, more fragmented, and increasingly isolated (Meffe and Carroll, 1997). The special characteristics of a riverine habitat, ie fish migration in rivers can only take place along given corridors which are often passable in only one direction, have facilitated these processes rendering many freshwater fish populations small and isolated (Pringle, 1997).

Population genetics theory predicts that in these populations, in the absence of migration and mutation, inbreeding and random genetic drift will result in increased homozygosity and loss of alleles (Hartl and Clark, 1997). Increased homozygosity could lead to a higher expression of deleterious recessive alleles, which will reduce fitness (partial dominance). In addition, if heterozygote advantage, or overdominance, is a general

Correspondence: G Knaepkens, University of Antwerp, Department of Biology, Universiteitsplein 1, 2610 Wilrijk, Belgium.

E-mail: guyknaep@uia.ua.ac.be

Received 28 January 2002; accepted 7 June 2002 phenomenon across the genome, increased homozygosity will also reduce fitness. The relative importance of these two processes remains unclear, but together they are known as inbreeding depression (Charlesworth and Charlesworth, 1987). Moreover, populations may lose alleles due to genetic drift, ie random fluctuations over generations in allele frequency as a consequence of random sampling. Although these alleles may be selectively neutral, they might become adaptive in future altered environmental conditions, or they may even be adaptive in the present environment. Thus both inbreeding and random drift lead to loss of genetic diversity, which may result in a reduced fitness, and ultimately, a reduced population viability (Hartl and Clark, 1997). Although evidence of associations between genetic diversity and fitness in wild species has been published (Saccheri et al, 1998), the lack of a comprehensive review across species and the existence of contradictory results, have led to the remaining scepticism about its existence and importance in natural populations (Thornhill, 1993; Britten, 1996; David, 1998; Crnokrak and Roff, 1999). Consequently, there is an urgent need for more studies on the relationship between genetic diversity and fitness.

The European bullhead (Cottus gobio L.), a small bottom-dwelling freshwater fish, is well suited for examining the relationship between genetic diversity and fitness related traits. In several European countries such as Belgium and Germany, the bullhead often has been forced into small and isolated populations, due to destruction, deterioration and fragmentation of their habitats (Lelek, 1987; Vandelannoote et al, 1998). Recent popu- 
lation genetic studies indicate that in these areas, levels of genetic variability differ considerably among bullhead populations and often are extremely low (Hänfling and Brandl, 1998a; Knapen et al, in press). Moreover it has been shown that such low levels of genetic diversity in these populations can largely be explained by both their small size and their high degree of isolation (Hänfling and Brandl, 1998b).

In this paper, we investigated the fitness consequences of such a loss in genetic variation by comparing levels of genetic diversity of bullhead populations and condition factor, a trait which is generally considered as a good indicator of fitness in fish (Danzmann et al, 1988; Kjesbu et al, 1991, 1992; Rakitin et al, 1999; Thelen and Allendorf, 2001) and which is easy to estimate (a length-adjusted measure of weight). However, other studies have indicated that, instead of genetic variability, other factors such as environmental conditions may be more important in determining the condition factor of fish populations. German trout (Salmo trutta) populations, for example, showed significant differences in condition factor depending on the conductivity of the water (Mebes, 1992; Hänfling, 1993), which is an indicator of the relative 'fertility' of the water (Moss, 1980). Similarly, Fortin et al (1996) indicated that conductivity is a major determinant of the condition factor of the lake sturgeon (Acipenser fulvescens). Therefore the impact of environmental factors on the condition factor of bullhead populations was also evaluated by examining the relationship between conductivity of the water and the condition factor. This way, the relative importance of both genetic variability and an environmental factor for the condition factor of bullhead populations was established. To evaluate the importance and generality of the observed patterns, our study was conducted in two different areas, in Flanders (northern part of Belgium) and Germany.

\section{Materials and methods}

\section{Study area and biological material}

Eleven German bullhead populations were sampled between May and June in 1994 and 1995. Eleven Flemish bullhead populations were sampled between November and February 1999 (Figure 1). The fish were caught with electric fishing gear (using a Electracatch WFC7 generator producing $150 \mathrm{~V}$ ) and each fish was measured (mm) and weighed $(0.1 \mathrm{~g})$ individually in order to calculate the condition factor (see section below). Due to the endangered status of the bullhead, sample size was sometimes relatively low. Sample size ranged between nine and 48 individuals (Table 1). Tissue samples were taken by finclipping and preserved in $100 \%$ ethanol at $-20^{\circ} \mathrm{C}$ prior to DNA extraction. The conductivity $(\mu S / \mathrm{cm})$ of the water was measured using a portable water flow-meter model $201 / 201 D$. Conductivity is a measure of the ability of water to pass an electrical current. It is determined by the total amount of dissolved ions in the solution and might therefore be a useful indicator of the relative 'fertility' or 'food availability' of the water (Moss, 1980).

\section{Genetic variability}

DNA was extracted by proteinase $\mathrm{K}$ digestion and salt precipitation (Aljanabi and Martinez, 1997). All samples were screened for variation at six microsatellite loci: Cgo310MEHU, Cgo56MEHU, Cgo91MEHU, Cgo1033PBBE, Cgo1114PBBE and Cgo34ZIM, according to the conditions described in Englbrecht et al (1999). PCR products were run on $6 \%$ denaturing polyacrylamide gels using an ALF Express DNA sequencer (Amersham Pharmacia Biotech). Allele sizes were estimated using AlleleLinks software (Amersham Pharmacia Biotech).

Microsatellite genotype frequencies were tested for deviations from the Hardy-Weinberg equilibrium (HWE)

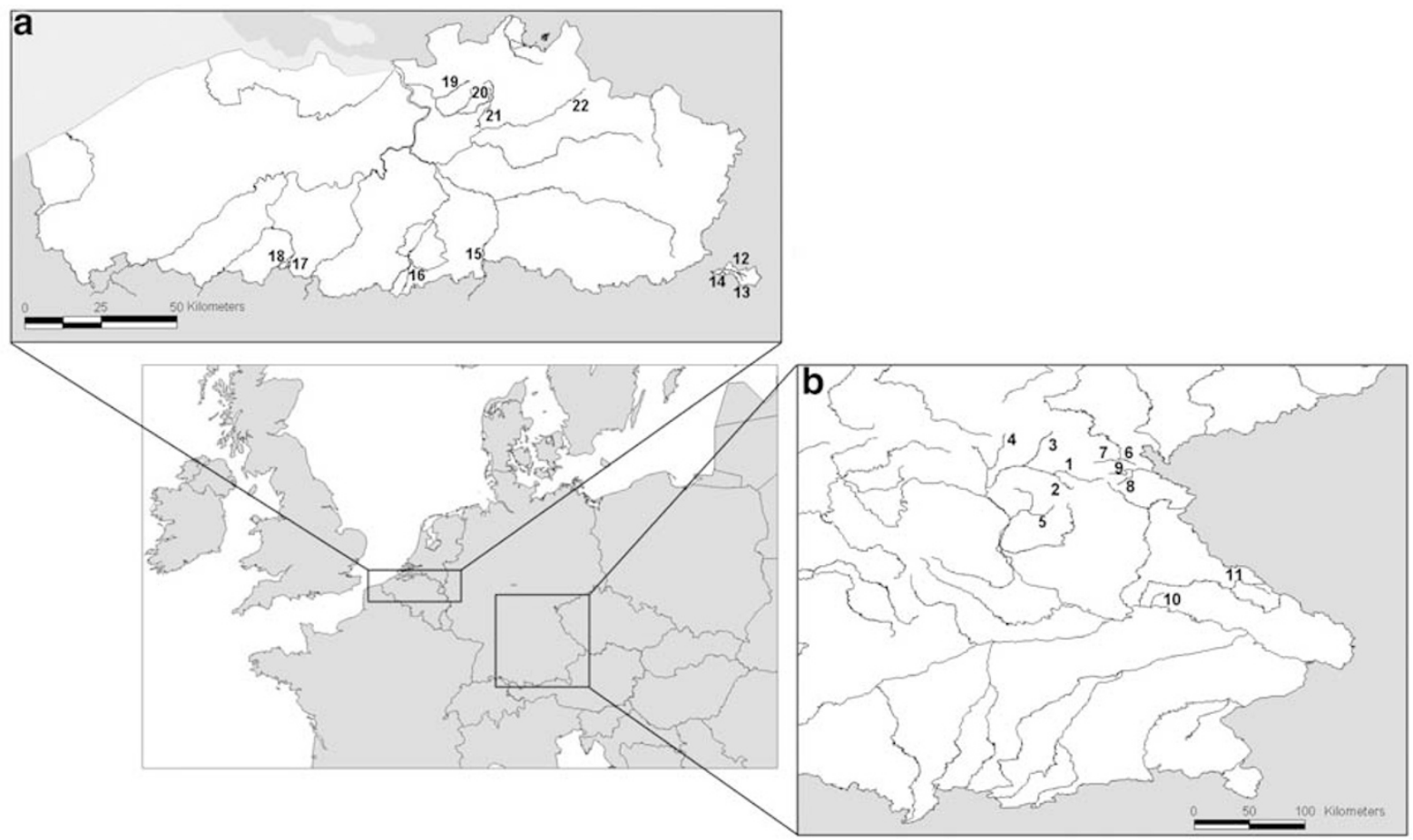

Figure 1 Distribution of sampled populations of Cottus gobio in Flanders (a) and Germany (b). Population numbers are listed in Table 1. 
Table 1 Drainage basin, sample size $(\mathrm{N})$, mean number of alleles (MNA), corrected mean number of alleles $\left(\mathrm{MNC}_{\mathrm{C}}\right)$, observed $\left(H_{\mathrm{O}}\right)$ and expected $\left(H_{\mathrm{E}}\right)$ heterozygosity, corrected observed $\left(H_{\mathrm{O}, \mathrm{C}}\right)$ and expected $\left(H_{\mathrm{E}, \mathrm{C}}\right)$ heterozygosity, condition factor $(\mathrm{K})$ and conductivity $(\mathrm{C}$; $\mu \mathrm{S} / \mathrm{cm}$ ) for German bullhead (Nr 1-11) and Flemish bullhead populations (Nr 12-22). /:no data available, SE: standard error

\begin{tabular}{|c|c|c|c|c|c|c|c|c|c|c|c|}
\hline$N r$ & Population & Basin & $N$ & $M N A$ & $M N A_{\mathrm{C}}$ & $H_{\mathrm{O}}$ & $H_{\mathrm{O}, \mathrm{C}}$ & $H_{\mathrm{E}}$ & $H_{\mathrm{E}, \mathrm{C}}$ & $K$ & $C$ \\
\hline 1 & WeisserMain & Rhine & 21 & 3.00 & 2.83 & 0.421 & 0.439 & 0.460 & 0.457 & 1.076 & 495 \\
\hline 2 & Mistelbach & Rhine & 14 & 1.50 & 1.26 & 0.036 & 0.028 & 0.036 & 0.027 & 1.014 & 270 \\
\hline 3 & Thiemitz & Rhine & 16 & 2.70 & 2.23 & 0.323 & 0.324 & 0.302 & 0.287 & 1.020 & 338 \\
\hline 4 & Itz & Rhine & 17 & 2.50 & 2.18 & 0.363 & 0.357 & 0.327 & 0.309 & 1.118 & 520 \\
\hline 5 & Leinleiter & Rhine & 24 & 2.70 & 2.26 & 0.333 & 0.319 & 0.332 & 0.309 & 1.113 & 613 \\
\hline 6 & Suedl. Regnitz & Elbe & 22 & 2.30 & 2.12 & 0.250 & 0.269 & 0.271 & 0.258 & 1.013 & 225 \\
\hline 7 & Enziusbach & Elbe & 18 & 2.30 & 2.33 & 0.417 & 0.415 & 0.359 & 0.340 & 0.909 & 235 \\
\hline 8 & Oedweissbach & Elbe & 17 & 1.80 & 1.77 & 0.196 & 0.184 & 0.217 & 0.179 & 0.973 & 195 \\
\hline 9 & Steinselb & Elbe & 17 & 2.70 & 2.45 & 0.363 & 0.359 & 0.368 & 0.337 & 0.927 & 180 \\
\hline 10 & Otterbach & Danube & 19 & 2.80 & 2.14 & 0.272 & 0.303 & 0.218 & 0.259 & 0.954 & / \\
\hline 11 & WeisserRegen & Danube & 19 & 5.30 & 4.22 & 0.535 & 0.502 & 0.584 & 0.547 & 0.934 & I \\
\hline Mean & & & & 2.69 & 2.34 & 0.319 & 0.320 & 0.321 & 0.300 & 1.005 & 341 \\
\hline SE & & & & 0.97 & 0.73 & 0.131 & 0.130 & 0.137 & 0.130 & 0.073 & 160 \\
\hline 12 & Veurs & Meuse & 37 & 1.33 & 1.20 & 0.032 & 0.055 & 0.053 & 0.059 & 1.039 & 646 \\
\hline 13 & Voer 1 & Meuse & 41 & 1.67 & 1.67 & 0.146 & 0.165 & 0.160 & 0.176 & 0.922 & 626 \\
\hline 14 & Voer 2 & Meuse & 14 & 1.34 & 1.58 & 0.143 & 0.156 & 0.143 & 0.141 & 1.037 & 638 \\
\hline 15 & Nethen & Scheldt & 14 & 2.83 & 2.60 & 0.321 & 0.333 & 0.455 & 0.439 & 1.076 & 849 \\
\hline 16 & Steenputbeek & Scheldt & 42 & 1.50 & 1.27 & 0.095 & 0.078 & 0.093 & 0.076 & 0.804 & 770 \\
\hline 17 & Verrebeek & Scheldt & 48 & 1.50 & 1.08 & 0.014 & 0.009 & 0.014 & 0.009 & 0.963 & 512 \\
\hline 18 & Molenbeek & Scheldt & 9 & 1.17 & 1.17 & 0.037 & 0.037 & 0.078 & 0.078 & 0.945 & 667 \\
\hline 19 & Laarse Beek & Scheldt & 43 & 2.50 & 2.15 & 0.271 & 0.279 & 0.325 & 0.304 & 1.044 & 464 \\
\hline 20 & Zwanebeek & Scheldt & 24 & 3.50 & 2.97 & 0.403 & 0.386 & 0.488 & 0.467 & 1.099 & 371 \\
\hline 21 & Tappelbeek & Scheldt & 21 & 6.62 & 5.14 & 0.659 & 0.704 & 0.674 & 0.661 & 1.331 & 458 \\
\hline 22 & Witte Nete & Scheldt & 11 & 2.17 & 2.11 & 0.348 & 0.348 & 0.343 & 0.321 & 1.288 & 416 \\
\hline Mean & & & & 2.37 & 2.08 & 0.224 & 0.232 & 0.257 & 0.250 & 1.049 & 584 \\
\hline SE & & & & 1.59 & 1.19 & 0.198 & 0.206 & 0.214 & 0.210 & 0.153 & 151 \\
\hline
\end{tabular}

with the Fisher exact test (Louis and Dempster, 1987) using GENEPOP 3.0 (Raymond and Rousset, 1995). To examine independence of the microsatellite loci, linkage disequilibrium between all pairs of loci was calculated using GENEPOP 3.0. Genetic diversity within populations was measured as the mean number of alleles per locus (MNA), mean observed heterozygosity $\left(H_{\mathrm{O}}\right)$ and mean expected heterozygosity $\left(H_{\mathrm{E}}\right)$ under HWE (Hartl and Clark, 1997) with GENETIX (Belkhir et al 1996). The different estimates of genetic variability were corrected for differences in sample size using the programme Doh (AssignmentTest; J. Brzustowski http://www.biology. ualberta.ca/jbrzusto/Doh.php/).

\section{Condition factor}

The study of condition, a standard practice in fisheries ecology, is based on the analysis of length-weight data and assumes that heavier fish of a given length are in better condition (Bolger and Connolly, 1989). In this study, we used the relative condition factor (K) which was calculated as follows (Le Cren, 1951; Ricker, 1971):

$$
K=\frac{w}{\hat{w}}
$$

The observed weight of each individual $(w)$ is compared with its expected weight $(\hat{w})$. The latter was estimated using a length-weight regression $\left(\hat{w}=\mathrm{al}^{\mathrm{b}}\right)$ of all caught individuals. $K$ indicates whether an individual is in better $(K>1)$ or worse $(K<1)$ condition than an average individual with the same length. At the population level, the average $K$ indicates whether a population is in better $(K>1)$ or worse $(K<1)$ condition than an average population. In other words, the condition factor allows the comparison quantitatively of the condition of two or more populations from different localities. The condition factor of fish is influenced by the stage of development of the reproductive organs (Lambert and Dutil, 1997). Therefore, when comparing the condition factor, it is important to sample the populations at the same time of the year so that the populations are at the same stage of the reproductive cycle. This is the case for the Flemish and German populations (see above), which means that condition factor at the population level can be compared within both areas. However, direct comparison of the condition factor at the population level between Flemish and German populations is not possible, because of different sampling periods.

\section{Data analysis}

We studied the relative importance of both genetic variability and one environmental factor (conductivity) for the condition factor of bullhead populations by means of multiple regression analysis (Sokal and Rohlf, 1997). Multiple regression models examine the relationship between a dependent and an independent variable when all other independent variables in the model are (statistically) held constant (Sokal and Rohlf, 1997). As the independent variables in these analyses, we used different estimates of genetic variability and conductivity. As dependent variable, we used the condition factor.

\section{Results}

In both German and Flemish bullhead populations, there was no evidence of genotypic linkage disequilibrium at any pair of loci (all $P>0.05$ ). After a tablewide Bonfer- 
roni corrected level of $\alpha=0.0006$, only one Flemish population (Nethen) showed a significant deviation from Hardy-Weinberg expectations at locus Cgo34ZIM $\left(F_{\mathrm{IS}}=+0.570, P=0.0001\right.$, data not shown). Most likely, this result was due to chance or to the presence of null-alleles.

Estimates of genetic diversity varied considerably among Flemish and among German bullhead populations (Table 1). In Flemish bullhead populations, the mean number of microsatellite alleles $\left(\mathrm{MNA}_{\mathrm{C}}\right)$ varied between 1.17 and 5.14, the observed heterozygosity $\left(H_{\mathrm{O}, \mathrm{C}}\right)$ between 0.009 and 0.704 and the expected heterozygosity $\left(H_{\mathrm{E}, \mathrm{C}}\right)$ between 0.009 and 0.661. In German bullhead populations, $\mathrm{MNA}_{\mathrm{C}}$ varied between 1.26 and $4.22, H_{\mathrm{O}, \mathrm{C}}$ between 0.028 and 0.502 and $H_{\mathrm{E}, \mathrm{C}}$ between 0.027 and 0.547 .

Furthermore, there was also a strong variation in both the condition factor and the conductivity of the water among Flemish and among German bullhead populations (Table 1). The condition factor of Flemish bullhead populations varied between 0.804 and 1.331 whereas in Germany the condition factor varied between 0.909 and 1.118. The values of conductivity in Flanders varied between 371 and 849, whereas in Germany, they varied between 180 and 613 .

The multiple regression analysis showed that betaweights (standardised regression coefficients) of genetic variability and conductivity differ among the Flemish and German populations (Table $2 \mathrm{a}$ and $2 \mathrm{~b}$ ). Therefore the influence of both factors on the condition factor is of a different magnitude in both groups. In Flanders, only the beta-weight of genetic variability was significant, while in Germany only the beta-weight of conductivity was significant. This analysis indicates that in Flanders, the condition factor and genetic variability are significantly positively related (Figure 2), while in Germany no relationship could be found between genetic variability and the condition factor. On the other hand, in Germany a significant positive relation was found between the condition factor and the conductivity of the water, while in Flanders this relationship was not significant (Figure 3).

\section{Discussion}

The data presented in this study clearly show that genetic diversity (both allelic diversity and multiple-locus heterozygosity) at microsatellite loci is strongly positively correlated with the condition factor among Flemish bull- head populations. To the authors' knowledge, this is the first time that such a correlation is observed at the population level of any freshwater fish species.

The condition factor is often associated with fitness: ie a poor condition can have several fitness consequences for individual fish and fish populations. Somatic growth potential of fish can be reduced (Danzmann et al, 1988). Reproductive success can be reduced through lower fecundity, reduction in egg quality or lower sperm quality (Kjesbu et al, 1991, 1992; Rakitin et al, 1999). Additionally, poor condition may also lower the chances of survival (Wilkins, 1967). Despite all these indications that in fishes the condition factor and fitness are correlated, it remains unclear at this moment whether this relationship holds in the bullhead.

However, if the condition factor is an appropriate estimate of fitness in bullhead populations, our results are in accordance with population genetics theory, that predicts that lower genetic variability decreases mean fitness of populations (Hartl and Clark, 1997; Lacy, 1997). Moreover, empirical evidence is accumulating that small and isolated populations that have been depleted of genetic variation often suffer a decreased fitness. Fragmented populations of the common toad (Bufo bufo) for example are characterised by significantly lower genetic diversity, survival and developmental homeostasis, compared to larger toad populations (Hitchings and Beebee, 1998). Similarly, remnant populations of the Florida panther (Puma concolor coryi) have, compared with larger populations of the species in western United States, low levels of genetic variation, poor sperm quality and high susceptibility to parasites (Roelke et al, 1993; O'Brien, 1994).

Despite the fact that a reduction of genetic diversity is often associated with a decreased fitness, a meta-analysis has shown that there is little empirical evidence to support the generality of this relationship (Britten, 1996). Although studies reporting negative results are expected to be under-represented, there are a few examples of studies providing evidence that a significant association among heterozygosity and fitness related traits did not exist (Whitlock, 1993; Brito and Coehlo, 1997). In the case of the endangered Sonoran topminnow (Poeciliopsis occidentalis) evidence from two separate studies even produced contradicting results. Whereas Quattro and Vrijenhoek (1989) showed that fitness traits were significantly related to levels of heterozygosity in topminnows, no such relationship was observed in the study of Sheffer et

Table 2 Multiple regression analysis of the condition factor $v$ genetic variability $\left(\mathrm{MNA}_{\mathrm{C}}, H_{\mathrm{O}, \mathrm{C}}, H_{\mathrm{E}, \mathrm{C}}\right)$ and conductivity in Flemish (a) and German (b) bullhead populations

\begin{tabular}{|c|c|c|c|c|c|c|c|c|}
\hline & d.f. & Condition factor & & d.f. & Condition factor & & d.f & Condition factor \\
\hline \multicolumn{9}{|c|}{ (a) Flemish bullhead } \\
\hline $\mathrm{MNA}_{C}$ & & $0.63(0.023)$ & $H_{\mathrm{O}, \mathrm{C}}$ & & $0.71(0.009)$ & $H_{\mathrm{E}, \mathrm{C}}$ & & $0.64(0.018)$ \\
\hline Conductivity & & $-0.33(0.181)$ & Conductivity & & $-0.26(0.236)$ & Conductivity & & $-0.34(0.157)$ \\
\hline $\mathrm{R}$ & 7.8 & $0.81(0.013)$ & $\mathrm{R}$ & 10.8 & $0.85(0.005)$ & $\mathrm{R}$ & 8.5 & $0.82(0.011)$ \\
\hline \multicolumn{9}{|c|}{ (b) German bullhead } \\
\hline $\mathrm{MNA}_{C}$ & & $-0.24(0.201)$ & $H_{\mathrm{O}, \mathrm{C}}$ & & $-0.27(0.116)$ & $H_{\mathrm{E}, \mathrm{C}}$ & & $-0.25(0.178)$ \\
\hline Conductivity & & $0.98(0.001)$ & Conductivity & & $0.99(0.0006)$ & Conductivity & & $0.99(0.0009)$ \\
\hline $\mathrm{R}$ & 17.9 & $0.92(0.0029)$ & $\mathrm{R}$ & 21.3 & $0.94(0.002)$ & $\mathrm{R}$ & 18.5 & $0.93(0.002)$ \\
\hline
\end{tabular}

Results are reported as beta-weights (standardized regression coefficients). Error probabilities are given in parentheses (significant results $P<0.05$ in bold) 

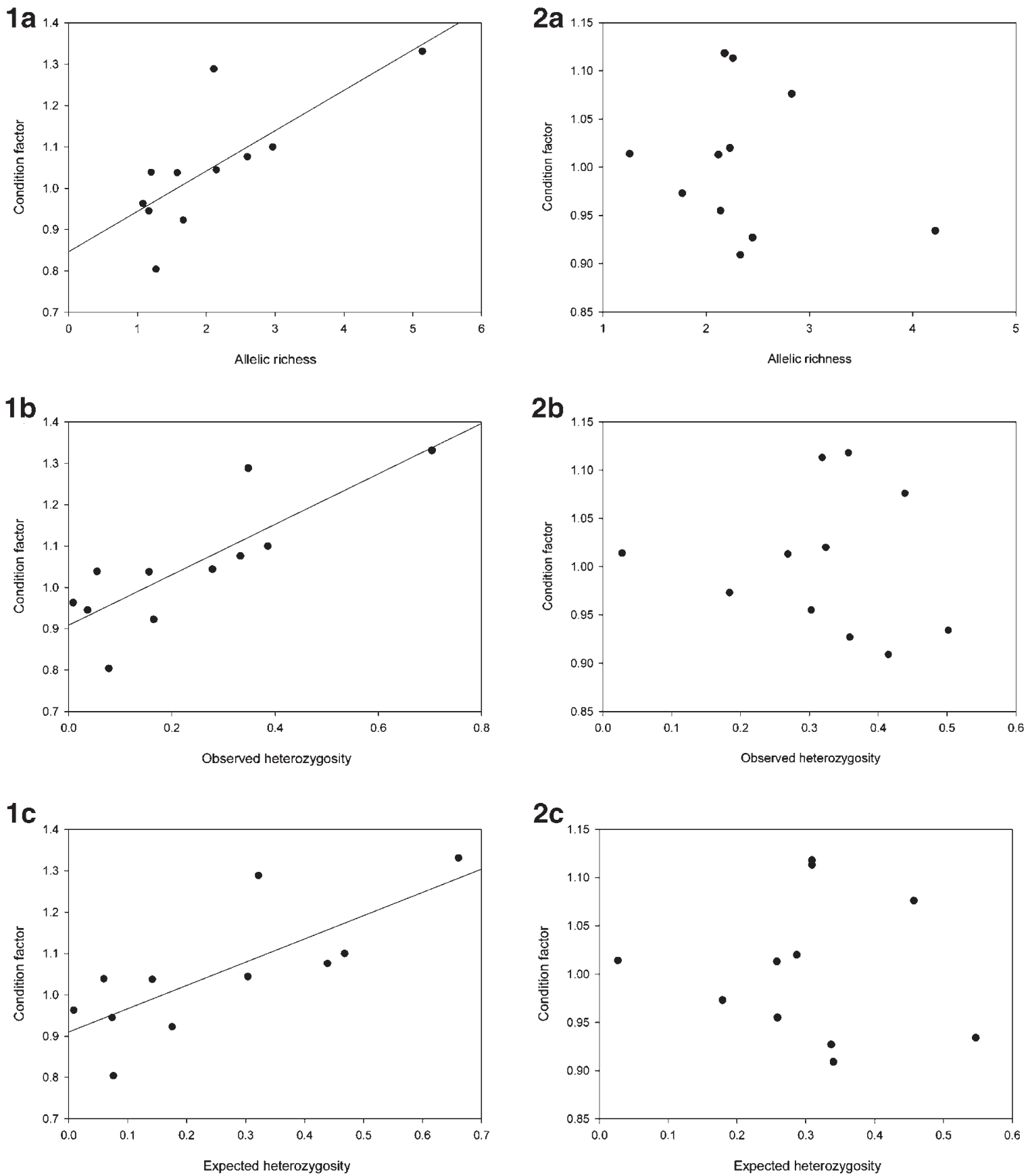

Figure 2 Correlation of allelic richness $\mathrm{MNA}_{\mathrm{C}}(\mathbf{a})$, observed heterozygosity $H_{\mathrm{O}, \mathrm{C}}(\mathbf{b})$ and expected heterozygosity $H_{\mathrm{E}, \mathrm{C}}$ (c) vs the condition factor for all investigated Flemish (1) and German (2) bullhead populations.

al (1997). This is similar to the observations in our study, where we find a positive correlation between genetic diversity and the condition factor among Flemish but not among German bullhead populations. We argue that several facts may (partially) explain these apparently contradicting results. First, whether or not a lower genetic diversity in a particular population is accompanied by a lower fitness may depend strongly on the history of that population (Husband and Schemske, 1996; Lacy and Ballou, 1998). Although demographic information about historical population sizes is lacking, it is known that Flemish bullhead populations have been under extreme pressure by anthropogenic activities such as pollution and habitat modification (Vandelannoote et al, 1998). Despite their sometimes small population size (Hänfling and Brandl, 1998b), most of the German populations are regarded as relatively undisturbed during recent decades (Schadt, 1993). This information is congruent with the results of tests for population bottlenecks based on 10 microsatellite data (independent of the present study, Hänfling et al, in press) which could show that six out of eight investigated Flemish bullhead showed signs of a recent population bottleneck. In contrast, in only four out of 18 studied German populations (including all of the 

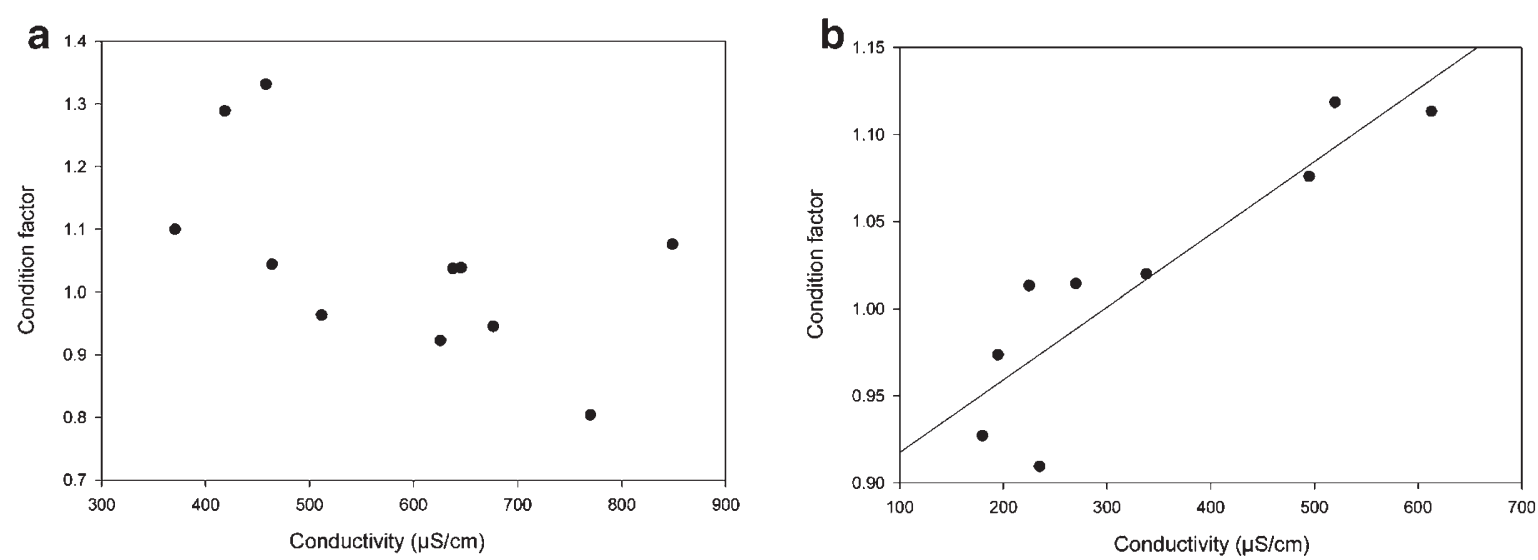

Figure 3 Correlation of the conductivity of the water $v$ s the condition factor for Flemish (a) and German (b) bullhead populations.

populations investigated in this study) recent population bottlenecks were evident. Populations that gradually reduce in size, or that are small for a relatively large number of generations, such as the German populations in this study, may experience relatively little permanent inbreeding depression, since selection is sometimes able to purge a population of deleterious alleles (Charlesworth and Charlesworth, 1987; Barrett and Charlesworth, 1991). Inbreeding depression may therefore be more prevalent in populations with historically large population sizes that now occur in small populations, such as our Flemish populations. Second, also environmental conditions such as food availability may determine the condition factor of fish populations (Weatherley, 1972) and this could mask the relationship between genetic variability and the condition factor. German trout (Salmo trutta) populations, for example, showed significant differences in the condition factor depending on the conductivity of the water (Mebes, 1992; Hänfling, 1993), which is an indicator of the relative 'fertility' or 'food availability' of the water (Moss, 1980). Similarly, Fortin et al (1996) indicated that conductivity of the water is a major determinant of the condition factor of the lake sturgeon (Acipenser fulvescens). This may also be the case for the German bullhead populations in this study, since both variables were significantly correlated. However, no such relationship was observed between the condition factor and conductivity among Flemish populations. Finally, we cannot rule out that the relationship between genetic variability and the condition factor in both areas varies due to differences in sampling period. However, to the best of our knowledge there is no published evidence that suggests that the relationship between genetic variability and fitness-related traits may change seasonally.

We are aware of only two other studies that have investigated the relationship between heterozygosity and the condition factor in fish species (Danzmann et al, 1988; Thelen and Allendorf, 2001). Although both studies also showed a positive correlation between both variables, this relationship was only investigated at the individual level using allozymes as genetic markers. Moreover, Thelen and Allendorf (2001) investigated the mechanisms underlying heterozygosity-fitness correlations because so far, it has proven extremely difficult to distinguish between competing explanations for the phenomenon that either treat the genetic markers as causative agents of the correlation ('direct dominance' hypothesis) or as neutral markers of linked deleterious genes ('associative overdominance' hypothesis). According to the 'direct dominance'-hypothesis, the heterozygosity-fitness correlation will only be expressed at markers (ie allozymes) having the potential to directly influence fitness characters and should not be expressed at presumably neutral markers (ie microsatellites). The 'associative overdominance'-hypothesis treats the genetic marker as neutral markers which are linked to deleterious genes. This explanation predicts that heterozygosity-fitness correlations will not be restricted to any particular type of genetic marker, provided that these have the potential to assess inbreeding levels or be linked to deleterious recessive genes. Thelen and Allendorf (2001) found that more heterozygous individuals of rainbow trout at allozyme loci had a significantly higher condition factor. In contrast, there was no evidence at microsatellite loci that increased heterozygosity was associated with a higher condition factor. Therefore they suggested that the observed relationship between heterozygosity and condition factor is due to the allozyme loci themselves, rather than associative overdominance. In our study we were not able to adequately investigate the relationship between heterozygosity and condition factor at the individual level due to the limited number of loci and individuals (per population). Nevertheless, at the population level, we found a positive correlation between heterozygosity (using microsatellite loci) and the condition factor in Flanders. We suggest that this possibly provides evidence that supports the associative overdominance hypothesis of the heterozygosity-fitness correlations. Clearly, further research at the individual level in bullhead populations would be required to adequately test this hypothesis. Such a study should involve more microsatellite loci and larger sample sizes, although the latter may not always be possible due to the endangered status of the fish species.

In summary, in the assumption that the condition factor is an appropriate estimate of fitness in bullhead populations, our results suggest that Flemish bullhead populations that have been depleted of genetic diversity are suffering a decreased fitness. This is in accordance with population genetics theory, inbreeding experiments and empirical studies of natural populations (Gjerde et al, 
1983; Hartl and Clark, 1997; Meffe and Carroll, 1997; Hitchings and Beebee, 1998; Keller and Waller, 2002). Nevertheless, our results also suggest that there may be different associations between levels of genetic diversity and the condition factor at the population level, even within a single species. Apparently, environmental conditions may also be important in determining the condition factor of bullhead populations. This emphasizes the importance of performing similar studies in different parts of the distribution range of a species, to get an unbiased idea of the generality and importance of the relationship of interest. In the case of the bullhead, a study of bullhead populations in only one area, may have led to different insights as to the relationship between genetic diversity and the condition factor at the population level. Clearly, there is much left to be understood about the association between genetic diversity and fitness related traits in natural populations; more studies are needed, and attention to positive as well as null results will allow elucidation of possible patterns and processes.

\section{Acknowledgements}

We thank T Dillen, M Taylor and V Mees for assistance in the field and/or in the laboratory. T Backeljau and P Galbusera provided comments and discussions which improved the quality of the manuscript. This work was supported by the University of Antwerp and AMINAL (VLINA/9903).

\section{References}

Aljanabi SM, Martinez I (1997). Universal and rapid salt-extraction of high quality genomic DNA for PCR-based techniques. Nucl Acid Res 25: 4692-4693.

Barrett SCH, Charlesworth D (1991). Effects of a change in the level of inbreeding on the genetic load. Nature 352: 522-524.

Belkhir K, Borsa P, Goudet J, Bonhomme F (1996). Genetix, logiciel sous Windows TM pour la génétique de population. Laboratoire Génome et Populations. CNRS UPR 9060, Université de Montpellier II, Montpellier.

Bolger T, Connolly PL (1989). The selection of suitable indices for the measurement and analysis of fish condition. J Fish Biol 34: 171-182.

Brito RM, Coehlo MM (1997). Lack of association between enzyme heterozygosity and fitness components in two Iberian cyprinids. Biologia 52: 663-668.

Britten HB (1996). Meta-analysis of the association between multilocus heterozygosity and fitness. Evolution 50: 2158-2164.

Charlesworth D, Charlesworth B (1987). Inbreeding depression and its evolutionary consequences. Ann Rev Ecol Syst 18: 237-268.

Crnokrak P, Roff DA (1999). Inbreeding depression in the wild. Heredity 83: 260-270.

Danzmann RG, Ferguson MM, Allendorf FW (1988). Heterozygosity and components of fitness in rainbow trout. Biol J Linn Soc 33: 285-304.

David P (1998). Heterozygosity-fitness correlations: new perspectives on old problems. Heredity 80: 531-537.

Englbrecht CC, Largiadèr CR, Hänfling B, Tautz D (1999). Isolation and characterization of polymorphic microsatellite loci in the European bullhead Cottus gobio L. (Osteichthyes) and their applicability to related taxa. Mol Ecol 8: 1957-1969.

Fortin R, Dumont P, Guénette S (1996). Determinants of growth and body condition of lake sturgeon (Acipenser fulvenscens). Can J Fish Aquat Sci 53: 1150-1156.

Frankel OH, Soulé ME (1981). Conservation and Evolution. Cambridge University Press: New York.
Gjerde B, Gunnes K, Gjedrem T (1983). Effect of inbreeding on survival and growth in rainbow trout. Aquaculture 34: 327332.

Hänfling B (1993). Wanderverhalten, Wachstum und Mortalität der Bachforelle Salmo trutta forma fario L. in zwei unterschiedlichen Gewässersystemen Oberfrankens und eine Betrachtiung der begleitenden Fischfauna. Diplom thesis, University of Bayreuth, Germany.

Hänfling B, Brandl R (1998a). Genetic differentiation of the bullhead Cottus gobio L. across watersheds in central Europe: evidence for two taxa. Heredity 80: 110-117.

Hänfling B, Brandl R (1998b). Genetic variability, population size and isolation of distinct populations in the freshwater fish Cottus gobio L. Mol Ecol 7: 1625-1632.

Hänfling B, Hellemans B, Volckeert FAM, Canvelho G. Late glacial history of the cold-adapted freshwater fish Cottus gobie, revealed by microsatellites. Mol Ecol (in press).

Hartl D, Clark AG (1997). Principles of Population Genetics, 3rd edn. Sinauer Associates: Sunderland.

Hitchings SP, Beebee TJC (1998). Loss of genetic diversity and fitness in Common Toad (Bufo bufo) populations isolated by inimical habitat. J Evol Biol 11: 269-283.

Husband BC, Schemske DW (1996). Evolution of the magnitude and timing of inbreeding depression in plants. Evolution 50: $54-70$.

Keller LF, Waller DM (2002). Inbreeding effects in wild populations. TREE 17: 230-241.

Kjesbu OS, Klungsoyr J, Kryvi H, Whitthames PR, Greer Walker M (1991). Fecundity, atresia and egg size of captive Atlantic cod (Gadus morhua) in relation to proximate body composition. Can J Fish Aquat Sci 48: 2333-2343.

Kjesbu OS, Kryvi H, Sundby S, Solemdal P (1992). Buoyancy variations in eggs of Atlantic cod (Gadus morhua) in relation to chorion thickness and egg size: theory and observations. $J$ Fish Biol 41: 581-599.

Knapen D, Knaepkens G, Bervoets L, Taylor MI, Eens M, Verheyen E. Conservation units based on mitochondrial and nuclear DNA variation among European bullhead populations (Cottus gobio L., 1758) from Flanders, Belgium. Conserv Genet (in press).

Lacy RC (1997). Importance of genetic variation to the viability of mammalian populations. J Mammal 78: 320-335.

Lacy RC, Ballou JD (1998). Effectiveness of selection in reducing the genetic load in populations of Peromyscus polionotus during generations of inbreeding. Evolution 52: 900-909.

Lambert Y, Dutil JD (1997). Condition and energy reserves of Atlantic cod (Gadus morhua) during the collapse of the northern Gulf of St. Lawrence stock. Can J Fish Aquat Sci 54: 2388-2400.

Le Cren ED (1951). The length-weight relationship and seasonal cycle in gonad weight and condition in the perch (Perca fluviatilis). J Anim Ecol 20: 201-219.

Lelek A (1987). The Freshwater Fishes of Europe, Vol. 9. Threatened Fishes of Europe. Aula-Verlag: Wiesbaden.

Louis EJ, Dempster ER (1987). An exact test for Hardy-Weinberg and multiple alleles. Biometrics 43: 805-811.

McNeely JA, Miller KR, Reid WV, Mittermeier RA, Werner TB (1990). Conserving the World's Biological Diversity. IUCN: Gland, Switzerland.

Mebes H (1992). Einfluss von Temperatur and Gewässerchemie auf das Wachstum und die Populationsstruktur der Bachforelle Salmo trutta forma fario L. in den geologisch unterschiedlichen Gebieten Oberfrankens. Diplom thesis, University of Bayreuth, Germany.

Meffe GK, Carroll CR (1997). Principles of Conservation Biology. Sinauer Associates: Sunderland.

Moss B (1980). Ecology of Freshwaters. Blackwell Scientific Publications: Oxford.

O'Brien SJ (1994). A role for molecular genetics in biological conservation. Proc Natl Acad Sci USA 91: 5748-5755.

Pringle CM (1997). Fragmentation in stream ecosystems. In: 
Meffe GK, Carroll CR (eds) Principles of Conservation Biology, Sinauer Associates: Sunderland. pp 289-290.

Quattro JM, Vrijenhoek RC (1989). Fitness diffferences among remnant populations of the endangered sonoran topminnow. Science 245: 976-978.

Rakitin A, Ferguson MM, Trippel EA (1999). Sperm competition and fertilization success in Atlantic cod (Gadus morhua): effect of sire size and condition factor on gamete quality. Can J Fish Aquat Sci 56: 2315-2323.

Raymond M, Rousset F (1995). GENEPOP (version 1.2): population genetics software for exact tests and ecumenicism. J Hered 86: 248-249.

Ricker WE (1971). Methods for Assessment of Fish Production in Fresh Waters. Blackwell Scientific Publications: Oxford.

Roelke ME, Martenson JS, O'Brien SJ (1993). The consequences of demographic reduction and genetic depletion in the endangered Florida panther. Curr Biol 3: 340-350.

Saccheri I, Kuussaari M, Kankare M, Vikman P, Fortelius W, Hanski I (1998). Inbreeding and extinction in a butterfly metapopulation. Nature 392: 491-494.

Schadt J (1993). Fische, Neunaugen, Krebse und Muscheln in Oberfranken. Vorkommen und Verbreitung als Grundlage für den Fischartenschutz. Bayreuth, Germany: Regierungsbezirk Oberfranken
Sheffer RJ, Hedrick PW, Minckley WL, Velasco AL (1997). Fitness in the endangered Gila topminnow. Conserv Biol 11: 162-171.

Sokal RR, Rohlf FJ (1997). Biometry, the Principles and Practice of Statistics in Biological Research, 3rd edn. W.H. Freeman and Company: New York.

Thelen GC, Allendorf FW (2001). Heterozygosity-fitness correlations in rainbow trout: effects of allozyme loci of associative overdominance? Evolution 55: 1180-1187.

Thornhill NW (1993). The Natural History of Inbreeding and Outbreeding: Theoretical and Empirical Perspectives. The University of Chicago Press: Chicago.

Vandelannoote A, Yseboodt R, Bruylants B, Verheyen R, Coeck J, Maes J et al (1998). Atlas van de Vlaamse Beek-en Riviervissen. Water-Energik-Vlario (WEL): Wijnegem.

Weatherley AH (1972). Growth and Ecology of Fish Populations. Academic Press: London.

Whitlock M (1993). Lack of correlation between heterozygosity and fitness in forked fungus beetles. Heredity 70: 574-581.

Wilkins NP (1967). Starvation of the herring, Clupea harengus L.: survival and some gross biochemical changes. Comp Biochem Physiol 23: 503-518. 